\title{
Raça, classe e ação afirmativa na trajetória política de militantes negros de esquerda
}

Claudete Gomes Soares'

\section{Resumo}

Passados dez anos da Conferência Mundial de Combate ao Racismo (2001), é possível dizer que a sociedade brasileira acomodou-se às experiências de ações afirmativas para a população negra. No entanto, quando esse debate se iniciou em 200I, permeado por todo o tipo de polêmicas, ele era novo também para os militantes do movimento social negro. Este artigo vai tratar dos dilemas e desafios que estiveram presentes na conversão da militância negra de esquerda às propostas de ações afirmativas. A nossa análise terá como referência a experiência da militância negra com atuação no Partido dos Trabalhadores que apostou na articulação entre raça e classe como estratégia de politização da questão racial. A adesão desse setor da militância às políticas de ações afirmativas para a população negra significou o confronto com as concepções políticas e ideológicas construídas no campo da esquerda.

Palavras-chave: Ações afirmativas. Luta de classe. Cidadania. Movimento Social Negro. Partido dos Trabalhadores.

\section{Apresentação}

Neste artigo exploraremos duas estratégias de politização da questão racial no Brasil: uma - que esteve na gênese da emergência do movimento negro contemporâneo na década de 1970 - se expressa por meio da articulação entre raça e classe; a outra - que tem como marco a Marcha Zumbi de 1995, mas só se completa com a Conferência Mundial de Durban em 2001 - se define pelas demandas de políticas públicas referenciadas à raça e à etnia, e de ampliação de direitos para a população negra.

I Professora Adjunta I da Universidade Federal da Fronteira Sul (UFFS), em Chapecó - Santa Catarina - Brasil da área de conhecimento de Sociologia e Política. Doutora em Sociologia pela Universidade Estadual de Campinas (Unicamp). Publicou artigos nas revistas Perseu: História, Memória e Política; Teoria e Debate; $e$ Ideias - Rev.doIFCH-Unicamp.E-mail: claudete.soares@uffs.edu.br. 
Trabalhamos com a hipótese de que o encaminhamento público que a questáo racial passou a ter a partir de 2001, quando da intensificaçáo das demandas do movimento negro por açôes afirmativas e pelas políticas de cotas, significou uma inflexão nos princípios políticos e ideológicos que guiaram setores significativos da militância negra, que iniciou sua atuação política na década de 1970 e 1980 e teve no campo da esquerda uma referência política para suas açóes e concepçóes político-ideológicas. A adesão dessa militância à nova forma de enfrentamento das desigualdades raciais, por meio da cidadania diferencialista, expressa pelas ações afirmativas, exigiu uma revisão, reelaboração, ressignificação de perspectivas anteriores, processo nem sempre vivido de forma tranquila.

Desenvolveremos essa reflexão com base nos dados de uma pesquisa sobre a questão racial e os projetos políticos do Partido dos Trabalhadores (PT), que nos possibilitou ter contato com as estratégias utilizadas pelo movimento negro e pela militância negra petista no processo de politização da questão racial no Brasil - bem como perceber os desafios e obstáculos colocados a uma geração de militantes que foi socializada politicamente no campo da esquerda e que em razão disso procurou politizar a questão racial a partir desse quadro de referência.

A politização da questão racial, ancorada na articulação entre raça e classe, será evidenciada com base nos elementos ideológicos que estiveram presentes na construção dos espaços de combate ao racismo na estrutura partidária do PT e nas intervençôes da militância negra ao interpelar e pressionar o partido objetivando o seu comprometimento político com a problemática racial. Ver-se-á que essa construção esteve claramente inserida em uma perspectiva que associava a questão racial a um projeto de transformação das estruturas capitalistas. Nesse ponto, nos preocuparemos em caracterizar essa militância negra, filiada a um projeto de transformaçáo da realidade social, por meio de suas experiências nos espaços de socialização política de esquerda.

A adesão às políticas públicas especiais para a população negra, na forma geral de açóes afirmativas ou na forma particular de política de cotas, implicou um processo de conversão a um tipo de política que a princípio não significa o questionamento ou a negação da forma de organização da sociedade capitalista. O que submeteu esse setor da militância negra a um dilema: aceitar as políticas públicas especiais referenciadas à raça seria abrir mão de um projeto 
de transformação social? A revolução podia ser ressignificada de forma que a conversão a essas políticas não implicasse a negação de um passado político? Ou seria necessário rever as posiçóes políticas e teóricas de forma a adequar o novo posicionamento diante da fase atual de politização da questáo racial no Brasil? Essas são questóes que aparecem nas entrevistas realizadas com alguns militantes negros participantes da construção dos espaços de combate ao racismo no PT - o qual se consolidou como o principal partido de esquerda na cultura política brasileira - e que podem ser encontradas também em alguns dos depoimentos coletados por Alberti e Pereira (2007), Histórias do Movimento Negro no Brasil: depoimento ao CPDOC.

Embora esses dilemas sejam aqui enfatizados por meio dos engajamentos individuais, e das estratégias de politização da questão racial, não podemos nos esquecer que eles fazem parte de um universo mais amplo que diz respeito à própria definição e redefinição de campos políticos: direita e esquerda, e que têm impactado as práticas militantes individuais.

\section{Trajetórias militantes: a identidade racial e o campo da esquerda}

\section{I.I A esquerda e a questão racial}

O movimento negro contemporâneo ${ }^{2}$ reemergiu no contexto de valorização da democracia e de crítica ao Estado autoritário no final da década de $1970^{3}$. Ao lado de outros movimentos, compôs o quadro de fortalecimento da sociedade civil que ocorreu no final de década de 1970 e começo de 1980. Uma das características dessa cojuntura é que vários dos movimentos e organizaçôes

2 Embora se tenha optado no texto pela denominação movimento negro ou, em alguns momentos, movimento negro contemporâneo, não se deseja com isso ocultar a diversidade e as divergências que caracterizam o movimento social negro no Brasil. Em razão do momento tratado, a década de 1980, a principal expressão do movimento negro no Brasil era o MNU (Movimento Negro Unificado), que foi formado por um conjunto de entidades, o que marca inclusive a sua diversidade interna. No entanto, sabemos que o movimento negro não se limita e nunca se limitou ao MNU, ele é constituido por uma teia de entidades e organizações com características e projetos diversos.

3 É preciso considerar que a organização política do negro teve lugar em vários momentos da história do Brasil: ora com maior capacidade organizativa ora com menos, são destaque na literatura sobre o tema: a Frente Negra Brasileira, a Impresa Negra e o Teatro Experimental do Negro, movimentos que antecederam as organizações e entidades negras que surgiram junto com a luta pela redemocratização. Ver: ANDREWS, G. $R$.

Negros e brancos em São Paulo 1888-1988. Bauru: Edusc, 1998. 
políticas que estavam compondo a nova cena política brasileira tinham na democracia uma palavra de ordem e identificavam-se com um projeto de transformação da realidade social. Em outras palavras, a utopia socialista estava fortemente associada aos anseios democráticos.

Em razão dessa conjuntura, também o movimento negro foi influenciado pela cultura política de esquerda e sua ênfase na luta de classes. Os ideais presentes na consolidação do Movimento Negro Unificado, que se formou em 1978, evidenciaram a necessidade política de se articular a raça à classe como parte da luta dos negros do Brasil. É essa mesma perspectiva que levou parcelas significativas dessa militância a se identificar com o socialismo petista da década de 1980 .

Além desse contexto interno, a militância negra que se formou no Brasil durante a ditadura e no contexto de abertura teve na luta dos negros norte-americanos pelos direitos civis e nos processos de independência dos países africanos, sobretudo, de língua portuguesa, outra importante referência política (MENDONÇA, 1996; PINTO, 1993).

A década de 1970 foi um período de reavivamento dos processos organizativos culturais e políticos referenciados à identidade racial, construção e descoberta da identidade racial e de suas possíveis formas de manifestação, que se expressou na criaçáo de organizaçóes como o IPCN (Instituto de Pesquisas das Culturas Negras) do Rio de Janeiro, SINBA (Sociedade de Intercâmbio Brasil-África), também do Rio de Janeiro, CECAN (Centro de Cultura e Arte Negra) de São Paulo, para citar apenas três das entidades negras que emergiram e se organizaram em várias regióes do país.

Quando no final dessa década (1978), a fusão de algumas dessas entidades (Moura, 1980, Hanchard, 2001) deu origem ao MNU (Movimento Negro Unificado), o movimento negro assumiu a árdua tarefa de desconstrução do mito da democracia racial que alimentava a concepção hegemônica das relaçóes raciais no Brasil, edificada sob a ideia de democracia racial. Concepçáo que foi sempre um obstáculo a apropriação da identidade étnico-racial como princípio de organização política.

Primeiramente, esse movimento teria que demonstrar a falsidade da democracia racial brasileira e resgatar a identidade negra subsumida na identidade nacional com o objetivo de ser reconhecido como uma força legítima, não 
apenas no campo político, mas também pela população negra. Enquanto os demais movimentos se alimentavam de experiências práticas e teóricas já existentes, as demandas políticas do movimento negro brasileiro estavam circunscritas à particularidade nacional de negação do racismo e de uma brasilidade construída a partir do mito das três raças, que teve como força transformar todos em brasileiros. "O mito das três raças é neste sentido exemplar, ele não somente encobre os conflitos raciais como possibilita a todos se reconhecerem como nacionais" (ORTIZ, 1985, p. 44).

Por esse motivo, por mais que o movimento negro tivesse se aproximado da concepção política que guiava as organizações políticas de esquerda ele não podia abrir mão do tema da identidade racial (GONZALEZ e HASENBALG, 1982). O fato de as organizaçóes de esquerda negligenciarem esse aspecto da luta política fez com que o casamento de setores da militância negra com a esquerda fosse pontuado por conflitos, tensóes e descontentamentos.

Ao tomarmos o processo de abertura política como um marco de referência, vemos que a militância negra que atuava nas organizaçóes de esquerda do período já estava diante de uma realidade que se reproduziria no histórico da politização do tema da questão racial no PT: a invisibilidade política do tema que lhe tocava mais de perto. É o retrato dessa realidade que vislumbramos no depoimento de Zélia Amador, militante negra, com passagem pela Ação Popular ${ }^{4}$ :

Dentro da Ação Popular, AP, não havia discussão em relação à questão racial. A questão era 'classe', não é? E continua sendo até hoje a grande premissa da esquerda brasileira. Quando entrei na AP, o livro de referência era o Liurinho Vermelho do Mao Tsé-Tung. E não se discutia a questão racial, essa era uma falta que eu sentia, inclusive. A grande máxima, digamos assim, era rejeitar o imperialismo dos EUA. E esse era um drama que eu carregava, porque tinha um lado daquela sociedade que eu gostava. Eu gostava dos Panteras Negras, eu gostava da luta pelos direitos civis, e carreguei comigo esse drama, durante todo o meu período de participação, porque você rejeitava o imperialismo, mas aquela era uma sociedade que tinha algo que me agradava. (ALBERTI e PEREIRA, 2007, p. 88)

4 A Ação Popular foi uma organização de esquerda com atuação entre 1962-1973 que se particularizava no contexto das organizações de esquerda do periodo pela sua base cristã e pela sintese entre cristianismo $e$ marxismo. Ver: RIDENTI, Marcelo S. "Ação Popular: cristianismo e marxismo". In: REIS FILHO, Daniel Aarão; RIDENTI, Marcelo (Org.). História do marxismo no Brasil, 5. Partidos e organizações dos anos 20 aos 60. Campinas: Ed. da UNICAMP, 2002. 
Os militantes negros que estavam desenvolvendo a consciência racial tinham, pois, nessas organizaçóes uma militância fragmentada ou incompleta. Isso porque o referencial da luta de classes, predominante nessas organizaçóes, levava, na melhor das hipóteses, ao silêncio em relação ao tema da questão racial, e, na pior, a sua deslegitimação enquanto tema político. Outro militante negro, com atuação no PCB, Yedo Ferreira, chega a dizer que embora houvesse uma ampla divulgação da imprensa sobre a luta pelos direitos civis dos negros nos Estados Unidos, ele, enquanto internacionalista, estava preocupado com a luta de classes. Foi a sua entrada na universidade e o contato com outros estudantes negros que o levou à questão racial: "deixei de ser internacionalista e fui ser defensor da questão racial.” (ALBERTI e PEREIRA, 2007, p. 136). Enquanto Zélia Amador expressa a incompatibilidade entre o reconhecimento da importância da luta dos negros norte-americanos e o referencial político de sua organização como um drama individual, Yedo Ferreira escolhe o caminho da ruptura, não só com a organização, mas com a cosmovisão que a alimentava.

Existe uma versão da história de formação do MNU (Movimento Negro Unificado) que o apresenta como resultado de um projeto originado no interior da Convergência Socialista (antes Liga Operária), a partir da ação de um grupo de militantes negros inseridos nessa organização: o Núcleo Negro Socialista. Essa versão, defendida por Gevanilda Santos (1992), faz parte das disputas por significado que caracterizam os movimentos sociais, ela vincula fortemente a origem do MNU à esquerda e sustenta que, em sua concepção original, esse movimento deveria ser uma frente contra todas as formas de discriminação que incluiria negros, mulheres e indígenas.

A importância da organização de esquerda para o surgimento do MNU aparece também em destaque na análise de Michael Hanchard (2001), ao falar da singularidade política desse movimento em contraste com o padrão culturalista dominante nas entidades no movimento negro brasileiro. O MNU, mesmo não estando imune ao culturalismo, teria, segundo esse autor, conferido uma dimensão política ao movimento negro no Brasil.

Em contraponto a essas abordagens, o documento de comemoraçáo de dez anos do Movimento Negro Unificado não faz referência à organização de esquerda, e sim às entidades culturais (Movimento Negro Unificado, 1988). 
Esse documento, segundo Milton Barbosa ${ }^{5}$, teria sido uma produção, sobretudo, do MNU da Bahia, e expressaria muito mais o movimento negro daquele estado. No entanto, ele, que militou na organização de esquerda mencionada por Gevanilda Santos (1992) e Hanchard (2001) e foi um dos fundadores do MNU em 1978, não estabelece uma relação direta entre a organização de esquerda e a formação do MNU. A sua fala, ao contrário, ressalta a divergência com organização.

Essas diferentes formas de percepção da história estão relacionadas às trajetórias militantes de quem a conta e às disputas que permeiam ou permearam o campo da politização da temática racial na sociedade brasileira. Milton Barbosa aponta o CECAN (Centro de Cultura e Arte Negra) como uma das organizaçóes embrionárias do MNU. Ao passo que Flávio Jorge Rodrigues da Silva acentua o Núcleo Negro Socialista, núcleo da Liga Operária (posteriormente Convergência Socialista), organização da qual ambos foram militantes. Enquanto Flávio Jorge permaneceu na Convergência e entrou no PT por meio do seu vínculo com essa organização, Milton Barbosa rompeu com a organização antes mesmo da formação do MNU em 1978 e de ela se transformar na Convergência em 1979. O seu ingresso no Partido dos Trabalhadores ocorreu em 1982, como militante fundador do MNU.

A Liga Operária foi uma pequena organização socialista e trotskista fundada em 1974 com atuação no movimento estudantil e nas lutas operárias. Em julho de 1977, a Liga muda de nome para PST (Partido Socialista dos Trabalhadores), que em 1978 lançou o movimento Convergência Socialista com o objetivo de aglutinar setores e militantes socialistas para a construçáo de um partido socialista. Esse processo resultou, segundo Antônio Ozai Silva (1987), na criação da Convergência Socialista em 1979, um dos agrupamentos de esquerda que estiveram na formação do PT.

\section{I.2 Raça e classe como estratégia política}

Os novos movimentos sociais se apresentaram na arena política como portadores de uma prática política alternativa respaldada na identidade e na autonomia como forma de diferenciação da política tradicional (PAOLI,

5 Entrevista realizada com Milton Barbosa no dia 18 de abril de 2008 em sua residência na zona oeste de São Paulo. 
1995; SHERER-WARREN e LÜCHMANN, 2004). Para o movimento social negro, os princípios da identidade e da autonomia eram muito caros, o que o levou a uma postura de desconfiança em relaçáo à política institucional: Estado, partidos, sindicatos.

Contudo, a atitude de desconfiança não implicou a negação do campo da esquerda como um espaço de organização política. Ao contrário, parcela significativa dessa militância, que foi formada na década de 1970, elegeu as organizações de esquerda como campo preferencial para sua atuação política geral ou como espaço de politização da questão racial. Em alguns casos, a atuação nessas organizaçóes precede, inclusive, a militância no movimento negro. Em sua síntese da história do movimento negro, Abdias Nascimento e Elisa Larkin Nascimento (2000) afirmam que essa identificação do movimento negro com a esquerda significou, inclusive, uma descontinuidade com a história e conquistas materializadas pelo movimento em períodos anteriores. É esse vínculo que explica a significativa aproximação do movimento do Partido dos Trabalhadores, a ponto de em algumas situaçóes o MNU (Movimento Negro Unificado) ser confundido com uma tendência do PT. Havia no MNU uma orientaçáo política para que o negro se organizasse nas várias esferas da sociedade, inclusive nos partidos.

Milton Barbosa, por exemplo, foi um dos fundadores da primeira Comissão de Negros do PT em 1982. Segundo ele, a formação desses espaços ocorreu a partir da percepção de que a intervenção nos diretórios do partido não era suficiente para a ampliação do debate sobre a questão racial. Era necessário desenvolver espaços específicos. No entanto, os espaços do partido e do movimento não se confundiam, nem mesmo geograficamente. Ele expressa a preocupação em guardar as diferenças entre o movimento e o partido que os movia: "A gente se reunia inclusive no escritório, no gabinete do Suplicy, tínhamos um problema de falta de espaço. Não era também no espaço do movimento negro para não ficar misturando." 6

A militância negra que passou a investir nesses espaços específicos partilhava da perspectiva dominante no partido: a centralidade da luta de classes, e era essa orientação partidária que legitimava a aproximação dessa militância do partido, como sintetiza o documento da Comissão de Negros do PT de 1982:

6 Entrevista realizada com Milton Barbosa, no dia 18 de abril de 2008 em sua residência na zona oeste de São Paulo. 
Nós entendemos o Partido dos Trabalhadores como aquele no qual os negros devem participar em função de sua composição de classe, pois é formado por operários, funcionários públicos, estudantes, médicos, engenheiros, enfim, trabalhadores em geral. E também pelo seu programa que coloca claramente a luta contra o regime dos patrões, ainda por seu compromisso com as lutas dos trabalhadores e oprimidos em geral, colocando na ordem do dia suas reivindicações. ${ }^{7}$

Após citar aspectos que revelam as péssimas condiçóes de vida da população negra - desemprego, violência policial, péssimas condiçóes de moradia -, o documento arremata: "Entendemos perfeitamente que outros segmentos também sofrem esse processo e que a luta central é entre pobres e ricos". Não por acaso a palavra de ordem do documento é "Contra a discriminação racial e a exploração do trabalhador".

Foi também a tentativa de dar um sentido prático à articulação entre raça e classe que levou a militância negra petista a defender o nome de Benedita da Silva como vice de Lula para as eleições presidenciais de 1989 no II Encontro Nacional "O PT e a Questão Racial” realizado em Vitória-ES, nos dias 26, 27 e 28 de agosto de 1988. Proposta que foi ratificada no documento da Comissão de Negros do Distrito Federal para o II Encontro do Negro do Centro-Oeste que seria realizado de 14 a 17 de abril de 1989. A militância entendia que uma candidatura que tivesse Lula e Benedita da Silva concretizaria uma política pautada na raça e na classe, conforme o documento:

Em pauta, Benedita da Silva, deputada negra, petista, para vice na chapa do companheiro Lula, operário ligado às históricas lutas dos trabalhadores. LULA e BENÉ. Um operário e uma mulher negra trabalhadora. Raça e Classe representando o perfil do oprimido brasileiro. Raça e Classe na mais perfeita combinação de luta a ser levada por todos nós, explorados raciais, sexuais, trabalhadores da sociedade brasileira ${ }^{8}$.

Benedita da Silva, pela sua trajetória política e origem social, é portadora de forte poder simbólico na arena política brasileira. Poder que está calcado em sua identidade política construída no campo dos movimentos populares ligados às mulheres e às condiçóes de vida dos moradores da

7 Comissão de Negros do PT - Partido dos Trabalhadores. O negro e o Partido dos Trabalhadores. Documento cedido por Milton Barbosa em entrevista no dia 18/04/2008.

8 Esse texto foi gentilmente cedido por Flávio Jorge Rodrigues da Silva e encontra-se nos arquivos da SNCR (Secretaria Nacional de Combate ao Racismo do PT) na sede nacional do partido. 
favela (MENDONÇA e BENJAMIM, 1997). Em 1982, com 17 mil votos, foi a vereadora mais votada do PT, exercendo seu mandato de 1983 a 1986 na cidade do Rio de Janeiro. No período seguinte - 1987-1990 - Benedita da Silva exerceu o mandato de deputada federal, também pelo PT, posição que ocupava quando da proposta para ser vice de Lula em 1989.

Os militantes negros produziram esse embate dentro do partido, apesar de a orientação partidária defender que o vice de Lula deveria ser de um dos partidos da frente eleitoral, como estratégia para ampliar a possibilidade de votos entre outros grupos ou classes, sobretudo a classe média. O documento intitulado "Brilha Brasil: Benedita da Silva, vice do Lula", assinado pelo Comitê de Apoio à Benedita vice de Lula9 , colocava em questão essa orientação partidária sob o argumento de que a aliança do partido deveria ser política, histórica e cultural com a totalidade da classe trabalhadora. Nesse caso o nome de Benedita da Silva teria maiores chances de atrair os setores excluídos da classe trabalhadora: favelados, e ainda contar com a simpatia da classe média intelectualizada.

Três argumentos respaldavam a defesa do nome de Benedita. Primeiro, o fato de ela ser uma moradora do morro e uma liderança entre os favelados, o que poderia ter impactos também sobre as donas de casa, ao reconhecerem o engajamento de Benedita da Silva com o movimento popular de mulheres; segundo, o fato de ser negra e mulher e ter um discurso que questiona o racismo e o machismo. E por fim, sua opção religiosa que possibilitaria a aproximação do partido com segmentos religiosos pouco simpáticos ao PT.

Apesar do engajamento da militância negra e de outros setores dos movimentos sociais pela aprovação do nome de Benedita para compor a chapa petista para as eleiçóes de 1989 (Raça \& Classe, 1989) ${ }^{10}$, o nome aprovado pelo partido foi o de José Paulo Bisol, do Partido Socialista Brasileiro (PSB), por contemplar os interesses dos demais partidos que compunham a Frente (PT, PSB, PC do B, PV).

Por ocasiáo do Centenário da Aboliçãa, o tema da questão racial veio à baila como um tema nacional (SCHWARCZ, 1989). Aproveitando essa

9 Dois documentos foram encontrados nos arquivos da Fundação Perseu Abramo sobre esse tema, basicamente com o mesmo conteúdo.

10 Raça E Classe era um jornal de informação e divulgação da Comissão do Negro do PT do Distrito Federal. 
conjuntura, a militância negra petista conseguiu introduzir essa discussão na resolução do $5^{\circ}$ Encontro Nacional do PT de 1987, que dizia da necessidade de articular a mobilizaçáo do Movimento Negro com a mobilização dos trabalhadores em geral (Diretório Nacional do PT, 1998, p. 339). Também a imprensa partidária foi ocupada pelo tema da questão racial. Militantes e intelectuais negros, bem como Florestan Fernandes, se empenharam em avaliar as debilidades do projeto partidário petista em conciliar a centralidade da luta de classes com a problemática racial. Vamos encontrar o debate raça e classe no artigo escrito por Hédio Silva Júnior, em maio de $1987^{11}$, no jornal do partido, Boletim Nacional, cujo título já é por si só significativo: "O PT e a questão racial: uma conversa, que não pode ficar só entre negros”. É também esse o foco do artigo de Florestan Fernandes escrito na Revista Teoria e Debate, intitulado "Luta de raças e de classes", que saiu em março de 1988, e dos artigos do número especial do jornal do partido, Boletim Nacional, dedicado ao Centenário, que saiu em maio de 1988. Esse número especial contou com artigos de Florestan Fernandes, uma entrevista com Olívio Dutra, feita por Hédio Silva Júnior, sobre a posiçáo do partido diante do tema e um artigo de Flávio Jorge Rodrigues da Silva, membro, na época, da Coordenação da Comissão de Negros do PT.

Todos manifestaram o descontentamento da militância negra petista com o tratamento dispensado pelo partido à temática racial no Brasil e tentavam apontar explicações para essa limitação. Para Hédio Silva Júnior (1988), o PT não se diferenciava da esquerda tradicional, pois, como aquela, via:

a emancipação da classe operária, como panaceia para todas as contradições experimentadas pelo nosso povo. [O PT] Não avançou no sentido de compreender o papel que a discriminação contra os negros desempenha na superexploração capitalista e na forma de dominação do autoritarismo brasileiro.

Traz também uma crítica às manifestações de solidariedade do partido, que, segundo ele, seriam vazias e passíveis de desprezo se não concretizadas em açóes políticas. Respaldado em dados que permitem falar em desigualdades raciais, Hédio Silva Júnior demanda uma resposta do PT. Segundo ele, esses

II Hédio Silva Júnior era, na época, membro da comissão de negros do PT. 
dados derrubam o mito da homogeneidade da classe trabalhadora, e seu tratamento uniformizado pelo capital.

O artigo de Florestan Fernandes (1988), na Revista Teoria e Debate, critica o discurso petista dominante sobre a questão racial, caracterizado pela manifestação de apoio e solidariedade, e conclama o PT a tomar posição na luta contra o racismo por meio da articulação entre raça e classe.

Era o vínculo que o partido guardava com a classe trabalhadora que atraíra a militância negra, em sua maioria originária e ideologicamente identificada com esse grupo social. Alguns dos militantes negros que foram para o PT estavam vinculados ao movimento sindical, com o qual o partido mantinha laços estreitos. As organizaçóes de esquerda e o ambiente universitário do final da década de 1970 e começo de 1980 foram outros espaços de socializaçáo política para essa militância.

Apesar de o projeto político partidário petista da década de 1980, centrado na luta de classes, ter atraído a militância negra para as fileiras do partido, a avaliação da militância é que essa centralidade levava ao silêncio sobre o papel do racismo no contexto da luta de classes, fazendo com que as discriminaçóes, opressóes e desigualdades raciais fossem subsumidas na perspectiva da classe.

No entanto, na década seguinte tanto o campo do movimento social negro como o campo político-ideológico do PT passariam por mudanças significativas. No se que refere ao projeto partidário, a década de 1990 é caracterizada por uma inflexão da centralidade da luta de classes e do socialismo petista, e pelo avanço do projeto que se orientava pela cidadania e pela ampliação dos direitos. O socialismo petista estava sendo substituído pela radicalização da democracia, enquanto objetivo partidário, o que reconfiguraria a relação do partido com a sociedade civil e com o Estado (SOARES, 2009).

No campo do movimento social negro, por sua vez, encontramos um processo de complexificação com a presença de novas organizaçóes e novos temas. A nacionalização do debate racial por ocasião do Centenário incentivou a organização da militância. Em 1988 foi criado o Geledés - Instituto da Mulher Negra - que, conforme Sueli Carneiro, é "uma organização política voltada para o combate ao racismo e ao sexismo e para a promoção das mulheres negras em particular e do conjunto da populaçáo negra em geral" (CARNEIRO, 2007, p. 280). Em julho do mesmo ano, surgiu a Unegro 
(União de Negros pela Liberdade) em Salvador, com o objetivo de articular a luta contra o racismo e as desigualdades raciais à luta de classes. ${ }^{12}$ A Unegro é identificada no campo do movimento social negro como um braço político do PC do B. A Soweto Organização Negra, criada em 1991, também é fruto desse processo, uma organização não governamental que aglutinou boa parte dos militantes negros paulistas vinculados ao PT.

É desse período a fundação do CEERT (Centro de Estudos das Relações Raciais e Trabalho), criado em 1990, por Hédio Silva Júnior e Maria Silva Bento. O CEERT tinha como objetivo fazer a ligação entre o movimento negro e sindical. Parte da militância negra que estava à frente dessas novas organizaçóes era aquela que tinha iniciado a sua militância na década de 1970 e começo de 1980. Outras organizaçóes não governamentais, com a atuação no campo do movimento social negro, seguiram a essas, a partir da segunda metade da década de 1990 .

Além da proliferação das ONGs negras, um marco importante na década de 1990 para o campo do movimento social negro foi a realização da Marcha a Brasília em 1995, por ocasião dos 300 anos da morte de Zumbi dos Palmares. A "Marcha Zumbi dos Palmares, contra o racismo, pela cidadania e pela vida" introduziu na esfera pública o tema das ações afirmativas para a população negra que só ganharia eco quando da III Conferência Mundial contra o Racismo, Discriminação Racial, Xenofobia e Intolerâncias Correlatas, realizada de 31 de agosto a 7 de setembro de 2001, em Durban, África do Sul.

Os dois campos políticos implicados nessa reflexão começam a ser povoados por novos significados sobre a luta política, o que desafiaria a visão política dos setores mais à esquerda nos dois campos. As respostas que a militância negra petista vinha procurando dar aos problemas das desigualdades, discriminações e preconceitos raciais não passavam pelas políticas públicas específicas para a população negra. As políticas eram pensadas de forma a conciliar a raça e a classe. À medida que o debate público sobre a questão racial foi sendo aprofundando a partir da perspectiva da cidadania, a militância negra petista teve que se confrontar com suas concepçôes ideológicas e com o seu entendimento da politização da questão racial no Brasil.

12 Cf.: Disponivel em: <http://www.unegro.org.br/historico.asp>. Acesso em: 15 jan. 2009. 


\section{A conversão às políticas de ação afirmativa: 0 enfrentamento de um dilema}

\section{I O universalismo guiado dos militantes negros petistas}

O encaminhamento público que a questão racial começou a ter em 1995 e se concretizou em 2001 - quando da intensificação das demandas do movimento negro por açóes afirmativas e por políticas de cotas - submeteu a militância negra petista a um dilema. Como legitimar o enfrentamento às desigualdades raciais na sociedade brasileira por meio da cidadania diferencialista, que alimenta as políticas de ação afirmativa, com o objetivo de criar uma elite ou burguesia negra, quando a politização da questão racial era vista como parte de uma luta contra as elites e a burguesia? E como, apesar disso, se opor a essas políticas, em uma sociedade táo racialmente hierarquizada como a brasileira, tendo em vista os aspectos simbólicos e culturais que se fazem presentes nas relaçóes de poder e de dominação?

Esse dilema teve lugar em razão das características das ações afirmativas, açóes com objetivos bastantes específicos que visam garantir o acesso de indivíduos negros nos espaços onde eles estão sub-representados e não se concretizam enquanto políticas de enfrentamento à pobreza. As políticas de açóes afirmativas atingem grupos bastante reduzidos da população negra e não toda a população negra, majoritariamente pobre. E, paradoxalmente, favorecem os negros mais capacitados que se deparam com a barreira racial em seu acesso aos espaços mais privilegiados da sociedade.

Por tudo isso, essa nova fase de enfrentamento das desigualdades raciais exigiu uma revisão, reelaboração e ressignificação da perspectiva que tinha orientado a atuação de setores da militância negra ligados ao campo da esquerda. As políticas públicas especiais para a população negra - em sua concretização ampla como ação afirmativa ou específica como política de cotas - não questionam ou negam a forma como a sociedade capitalista se estrutura, ao contrário, se acomodam aos princípios que regem essa sociedade.

As ações afirmativas operam no nível da estratificação social e não da estrutura de classes. Mesmo que impliquem uma visão coletiva do direito, uma vez que se direcionam a indivíduos pertencentes a grupos específicos: racial, étnico ou sexual, seu objetivo é minimizar os obstáculos que impedem a alguns indivíduos, em razão de seu pertencimento grupal, obterem as recompensas 
resultantes de suas habilidades e serviços negociáveis no mercado. Em outros termos, as açóes afirmativas náo questionam as desigualdades inerentes à estrutura de classe, mas atuam nos aspectos que promovem os desvios do status de igualdade que a cidadania deveria garantir. É por isso que para Guimarães (1999) as políticas de ações afirmativas são uma defesa da "desracialização, desetnização ou dessexualização de elites, e não num ataque à formação de elites" e preveem a formaçáo de uma classe média ou burguesia negra:

Apesar de não parecer claro ao senso comum, o princípio da ação afirmativa encontra seu fundamento na reiteração do mérito individual e da igualdade de oportunidades como valores supremos: a desigualdade de tratamento no acesso aos bens e aos meios justifica-se, apenas, como forma de restituir a igualdade de oportunidades, e, por isso mesmo, deve ser temporária em sua utilização, restrita em seu escopo, e particular em seu âmbito [...] Já se vê, portanto, que a ação afirmativa surge como aprimoramento jurídico de uma sociedade cujas normas e mores se pautam pelo princípio da igualdade de oportunidades na competição entre indivíduos livres [...] (p. 181).

É em razão dessas características que a conversão de militantes negros socializados no campo da esquerda foi vivenciada na forma de um dilema. Defender políticas públicas específicas referenciadas à raça seria abrir mão de um projeto de transformação social? A revolução poderia ser ressignificada de forma que a conversão a essas políticas não significasse uma ruptura com o passado político? Ou seria necessário rever as posiçôes políticas e teóricas de forma a adequar-se à fase atual de politização da questão racial? Essas são questóes que aparecem nas entrevistas realizadas com os militantes negros que participaram da construçáo dos setoriais de combate ao racismo do PT e que podem ser encontradas também em alguns dos depoimentos coletados por Alberti e Pereira (2007).

Pode-se dizer que a ação, a intervenção e o diálogo da militância negra petista com o partido eram conduzidos pelo que Lívio Sansone (1998) chamou de universalismo guiado em sua oposição às políticas específicas para a população negra, sob o argumento de que a elaboração e eficiência dessas políticas dependem de grupos étnicos bem definidos. $\mathrm{Na}$ ausência desses grupos, na sociedade brasileira, ele propóe o universalismo guiado que:

pressupõe medidas locais, regionais, para determinadas camadas sociais, intervir em algumas regiões, cidades, bairros ou no mercado de trabalho no quais se concentram a 
pobreza, o desespero e a injustiça. Quer dizer de forma quase automática, alcançar as grandes massas de negros sem, necessariamente, pressupor uma organização de base étnica (1998, p. II).

São justamente esses princípios que norteavam a concepção de políticas especiais para a população negra entre os militantes petistas engajados com o combate ao racismo, que encontramos, por exemplo, na proposta dos negros petistas para o programa de governo do PT nas eleiçóes presidenciais de 1989. Essa proposta foi elaborada por Hédio Silva Júnior com o objetivo de circular entre os militantes negros petistas para debates e acréscimos, podemos considerá-la, portanto, uma expressão da concepção da militância negra ligada ou organizada nos setoriais de negros e negras do partido. Assinalava-se a particularidade da população negra, mas as políticas eram pensadas segundo princípios de universalidade, como indicam os dois elementos que destacamos:

a) criar programas especiais de formação de mão de obra que privilegiem as periferias dos centros urbanos e setor rural; assegurar através de leis e fiscalização o combate ao racismo no trabalho;

b) criar programas especiais de alfabetização de jovens e adultos em especial nas periferias e setor rural; ampliar e melhorar a rede de ensino na cidade e no campo e assegurar que a elaboração dos currículos escolares contemple e respeite as diferentes etnias que conformam a população brasileira.

Arremata o texto de proposta: "Não há dúvida quanto ao fato de que medidas como estas beneficiam negros e brancos, porém o seu impacto será maior, sem enganos, sobre os negros"13.

Ambas as propostas, tanto da militância negra petista, quanto de Lívio Sansone, fazem uma aposta em políticas universais de combate à pobreza como forma de alterar as defasagens materiais experimentadas pela população negra. No entanto, a posição de Lívio Sansone (1998) já está inscrita nas disputas políticas e teóricas que marcariam o campo das relaçóes raciais na segunda metade da década de 1990, enquanto a posição da militância reflete a compreensão da politização da questão racial dominante no movimento negro no final da década de 1980.

13 Subsecretaria Nacional de Negros do PT. Políticas sociais para a população negra no Plano Alternativo de Governo, 1989 (Documento cedido por Flávio Jorge Rodrigues da Silva). 
A predominância do universalismo guiado entre os militantes negros petistas foi detectada também quando eles foram indagados sobre a influência que a aprovação do percentual de $30 \%$ de cotas para mulheres na direção do partido no I Congresso do PT em 1991 teria tido sobre a militância negra petista. A pergunta era se a experiência das mulheres teria levado a pensarem nesse caminho para a ampliação de espaços para os negros no partido:

Não pensamos nisso não... não pensamos. E mesmo porque, e daí? [...] No movimento negro, a gente sempre fez crítica à ausência de negros, nas várias instâncias, isto está no documento [documento da Comissão dos Negros do PT], mas nunca exigimos uma quantia $x, 10 \%$, que seja, não foi esse o nosso caminho. (Milton Barbosa ${ }^{14}$ )

Nós nunca fizemos essa discussão de cotas para negros. [...] Nós preferimos fazer esse embate direto com as direções. É claro que isso traz problemas, você tem menos negros nas direções, tanto nas nacionais, estaduais. Quando você pega nas eleições, a nossa participação fica restrita. Mas foi uma opção, nós não fizemos... nós, em um primeiro momento, nós, quando as mulheres se estruturam dessa forma 30\%, nós... será que esse é o nosso caminho. Nós avaliamos que não. (Flávio Jorge ${ }^{15}$ )

Eu, digo a você com sinceridade, eu nunca me expressei, até porque eu nunca fui demandado, nunca houve... pelas cotas, na minha militância, nem contra nem a favor até 1994 , 1995... nem quando se discutiu, se consolidaram as cotas para mulheres no partido eu coloquei essa questão [...]. (Nilo Rosa ${ }^{16}$ )

Essa discussão sempre aparece, sendo que nunca foi pra voto nesses momentos cruciais de definição, como congressos, nunca houve a apresentação de uma proposta acabada sobre a consideração de cotas para negros no partido. O que nós investimos foi na estruturação de espaços que é a Secretaria ${ }^{17}$, que existe até hoje, e também a estruturação das políticas." (Matilde Ribeiro)

Essa posição da militância negra petista diante da deliberação de cotas para as mulheres reflete o estágio de organização do movimento negro brasileiro,

14 Entrevista realizada com Milton Barbosa no dia 18 de abril de 2008 em sua residência na zona oeste de São Paulo

15 Entrevista realizada com Flávio Jorge Rodrigues da Silva no dia 06 de novembro de 2007 na Fundação Perseu Abramo.

16 Entrevista realizada com Nilo Rosa no dia $1^{\circ}$ de agosto de 2008 em Goiânia no V COPENE (Congresso Nacional de Pesquisadores Negros).

17 Matilde Ribeiro refere-se aqui à Secretaria Nacional de Combate ao Racismo do PT (SNCR) constituida em 1995 como um setorial do partido. Entrevista realizada com a então secretária da SEPPIR (Secretaria Especial Para a Promoção da Igualdade Racial) Matilde Ribeiro, no dia 05 de novembro de 2007, no Hotel Pestana em São Paulo. 
que não tinha no começo da década de 1990 uma pauta em torno das açóes afirmativas.

\subsection{Corrigir ou reformar: os termos do dilema}

A necessidade de se tomar uma posição diante das políticas específicas para a população negra ocorreu quando da difusão das propostas de ações afirmativas e exigiu da militância negra o confronto com certo tipo de identidade política construída no campo da esquerda. A militância negra petista viveu politicamente o que Nancy Fraser (2005) elaborou, teoricamente, como o dilema entre corrigir ou transformar. Orientados politicamente por uma concepção de mundo que mirava as causas estruturais das desigualdades, a compreensão que tinham de políticas especiais visava aos nichos de pobreza, considerados espaços da classe trabalhadora e entre ela os trabalhadores negros. Essa concepção não se afinava com a orientação que está subentendida na política de ações afirmativas, pelo fato dessas iniciativas não atingirem o nível no qual a divisão do trabalho é racializada ou implicar em impactos materiais diretos para os setores mais pobres da população: brancos ou negros.

Esse dilema aparece de uma forma bastante intensa no depoimento de Hédio Silva Júnior CPDOC (ALBERTI e PEREIRA, 2007). Ele participou dos setoriais de combate ao racismo do PT e fez parte do Comitê responsável pela preparação da participação brasileira na Conferência de Durban, sendo o relator do documento que o Brasil levou à Conferência. Em relação a esse documento, Hédio Silva Júnior se expressa da seguinte maneira: "Quem ler o documento que o Brasil levou para a África do Sul vai ver que tem um monte de proposições. Mas a mídia destacou 'cota na Universidade'. Para nós foi bom inclusive. Olhando com o olhar de hoje não foi táo ruim, foi bom” (SILVA JÚNIOR, 2007, p. 378, grifo nosso).

Na sequência, evidencia as tensôes, os dramas e as resistências dessa militância em relaçáo à direção que a política de combate ao racismo ganhou com e após a Conferência de Durban:

Em muitas reuniões, o Hélio Santos era uma voz solitária a favor das ações afirmativas. Também o Carlos Medeiros, no Rio de Janeiro. Enfim, algumas figuras sacaram bem antes de nós que isso era importante. E depois eu fui me interessando por esse tema. Foi uma maturação muito lenta e também muito dolorosa. Porque em vários momentos estava em questão se a adesão a um tipo de reivindicação como esta significaria ou não uma rendição 
ideológica: nós que amávamos tanto a revolução, agora, estaríamos, digamos assim, contentes de partilhar o bolo sem a transformação social. Até que alguém disse que nós estávamos fazendo uma extraordinária transformação social das relações do cotidiano, das relações dos microespaços de poder. E a própria questão do empoderamento da população negra e a coisa mais altiva, mais ousada na política, nas relações intersubjetivas. Alguém precisou dizer que a gente estava fazendo a revolução, que cotas no Brasil é revolução. E a história está mostrando que é revolução. Possivelmente na República não houve um tema que tenha mobilizado tanta energia quanto a questão das cotas, a favor e contra. Então a gente começou a pensar que era legal, que era uma revolução. Acho que isso é mesmo sinal de ruptura com um certo pensamento bastante "rastaquera" e bastante precário, mal sintetizado, que é a leitura que a esquerda propunha que nós fizéssemos da realidade brasileira. Então eu acho que a nossa geração deu passos, está dando passos, porque foi capaz de romper. Mas a ruptura foi dolorosa, custou caro pra muita gente. ${ }^{18}$ (Idem, p. 397).

A adesão às políticas de ações afirmativas como um enfrentamento ideológico com a trajetória militante anterior aparece também nas entrevistas que fiz com Milton Barbosa (Miltão) e Flávio Jorge (Flavinho). Ambos mostraram-se reticentes, resistentes ao revelarem suas posiçóes pessoais diante dessas políticas tendo como referência um suposto perfil político-ideológico da elite negra norte-americana formada por meio dessas políticas. Flávio Jorge afirma que precisou ser convencido da legitimidade dessas políticas para se posicionar favoravelmente a elas:

18 Hédio Silva Júnior tem um histórico de engajamento intenso no campo do combate ao racismo, a partir de sua atuação nos setoriais de combate ao racismo do PT e de sua ligação com o movimento sindical e 1991 com a criação da ONG CEERT. Em 1988 fez parte da Comissão do Centenário, formada por militantes negros petistas e foi uma das vozes críticas ao tratamento dispensado pelo PT à questão racial. A partir de 1990 não se filia mais ao PT, mas continua apoiando os candidatos petistas (Dep. Fed. Vicentinho, Vereadora Claudete Alves, Dep. Est. Tiãozinho) e continuava a ser identificado politicamente no campo do combate ao racismo como petista. Em 2005 foi convidado pelo governador do Estado de São Paulo Geraldo Alckmin a assumir a Secretaria de Justiça do Estado de São Paulo. Em 2006 foi candidato a deputado federal pelo PFL, atual DEM, conforme informações prestadas na entrevista que me concedeu por e-mail. Em entrevista à revista Isto É em 2005, justifica a sua indicação para Secretário da Justiça como uma estratégia de aproximação do governo Alckmin dos movimentos sociais. Nessa mesma entrevista. Hédio Silva Júnior diz que entende que houve alterações na relação entre os movimentos sociais e os partidos. "Durante muito tempo, essa ideia de movimento social no Brasil estava vinculada à esquerda. Hoje, esse quadro pode estar sofrendo alterações. $A$ Associação da Parada Gay de São Paulo, por exemplo, não tem explicitamente uma inclinação para esse ou aquele lado do espectro político. É possivel que a esquerda tenha perdido uma certa hegemonia que deteve durante muito tempo em algumas formas de organização social. $\mathbf{O}$ próprio movimento negro não traz mais o selo partidário de $\mathbf{2 0}$ anos atrás. Naquela época, seria uma heresia admitir um vínculo com um partido tido como liberal ou mesmo conservador. Hoje, é absolutamente normal que isso aconteça”. Cf Isto é. São Paulo, n.1876, set. 2005. (grifos nossos) 
É... até por eu ter vindo de um agrupamento desse tipo, um agrupamento ligado à Convergência Socialista, num primeiro momento a gente rechaça essa discussão de cotas, com uma visão, que hoje eu considero equivocada, mas um pouco comparando à política de cotas nos EUA. A gente compreendia que nos EUA nós criamos uma elite negra cujas figuras estão aí até hoje, eles já vêm lá de trás. Então isso era muito... como a gente tinha uma visão dita internacionalista, você fazia uma ponte com o que ocorreria no movimento negro americano, principalmente. E nós discordávamos de você importar uma política do movimento negro americanos pra cá. Com o tempo eu fui sendo convencido, e não só eu como quase toda a nossa geração, de que a política de cotas ela é necessária no Brasil, dado o grau de desigualdade que você tem, principalmente na educação. Mas foi, foi um processo, tenho que ser honesto em falar isso. Num primeiro momento a gente não concorda com a política de cotas.

Em seu depoimento ao CPDOC (ALBERTI e PEREIRA, 2007), Flávio Jorge expóe a preocupação com o caráter individualista dessas políticas: "Se ela não for acompanhada de um processo de formação política muito grande - e aí a ação do movimento negro é fundamental -, a gente pode construir uma elite política no país, mas uma elite política individualizada" (p. 409).

A negatividade da experiência norte-americana é ressaltada também na fala de Milton Barbosa, quando afirma que ainda guarda desconfianças em relação a essas políticas: "A opção das cotas... eu, particularmente, ando muito cabreiro com as cotas, entendeu?” Milton Barbosa justifica essa posição tendo em vista que o resultado dessas políticas nos EUA foi a formação de uma elite negra acomodada ao stablishement norte-americano. Se ele não se opóe publicamente a elas é por entender que essas políticas têm desempenhado a função de promover o debate na sociedade e de acordo com suas próprias palavras "tirar os racistas do armário":

Mas aqui no Brasil, você tem que de fato partir de alguma coisa pra estar alterando essa realidade extremamente desigual que quase $100 \%$ das cotas são dos brancos, em tudo na universidade, no trabalho [...] lógico que levando em conta o salário, o grau de insalubridade, aquelas coisas todas. Aquele trabalho, muito pesadão, mal remunerado... Então, o que gente percebeu também é que os racistas saíram do armário aqui e começaram a atacar as cotas. Os racistas, porque eles querem os privilégios, eles querem o privilégio pra eles de 100\%. Então, não tem como você, a gente tem que defender cotas. Mas nós [MNU] somos por reparações ${ }^{19}$. Na verdade é uma discussão que a gente tem."

19 O conceito de reparação utilizado no campo do combate ao racismo no Brasil carece de definições, alguns entendem que a reparação deve ser feita por meio de indenizações econômicas. Na Conferência de Durban 
Os resultados negativos da política de cotas são nomeados em alguns desses depoimentos em frases como "o risco de criação de um Colin Powell ou de uma Condeleezza Rice". A ideia de que a política de cotas pode favorecer a um grupo de pessoas que não tem compromisso com nada, a não ser com a ascensão social, se repete nos depoimentos daqueles que tiveram de rever suas posiçóes para reconhecer a legitimidade da política de cotas.

As representaçóes dos Estados Unidos têm ocupado um lugar especial nas disputas sobre as relações raciais no Brasil, seja entre a militância, influenciando posiçóes políticas, seja no debate teórico quando se trata de definir a validade ou não do conceito social de raça. A influência da experiência norte-americana como um balizador, ora positivo, ora negativo das políticas de açôes afirmativas resulta da cristalização da concepção de que o modelo de política racial brasileiro - a democracia racial - se construiu em oposição ao modelo norte-americano, caracterizado pela separação e identificação racial dos indivíduos. Para os que defendem essas políticas, o lado positivo do modelo norte- americano foi ter gerado um contexto de solidariedade racial e de organização política orientada pela identidade grupal e como resultado dessa organização a implementação de políticas especiais para a população negra.

Para os que se opóem às políticas de ações afirmativas, falar em políticas específicas para a população negra no Brasil trata-se de mera importação da experiência norte-americana para uma realidade que se constituiu por meio de outros princípios. A radicalização dessa concepção chega a apontar o debate brasileiro contemporâneo sobre as relaçôes raciais como um projeto das instituiçôes e de intelectuais norte-americanos visando à racialização das relaçóes sociais na sociedade brasileira. ${ }^{20}$

a reivindicação permeada pela ideia de reparações pressupunha perdão de dividas externas dos países africanos com os países europeus em razão da colonização e do tráfico de escravos.

20 Sobre as disputas teóricas em torno das relações raciais na sociedade brasileira, ver: BOURDIEU, Pierre; WACQUANT, Loïc. "Sobre as artimanhas da razão imperialista”. In: Estudos Afro-Asiáticos, ano 24, n I, 2002. O artigo de Bourdieu e Wacquant, originalmente publicado na revista francesa Actes de la Recherche en Sciences Sociales, em 1998, é uma crítica ao liuro de Hanchard Orpheus and Powuer (1994), que trata do movimento negro no Rio de Janeiro e em São Paulo. Hanchard é acusado pelos autores franceses de transformar conceitos particulares à realidade norte-americana em universais ao aplicar as categorias raciais norte-americanas para explicar as relações raciais no Brasil. Mais do que isso, enquadram as reflexões de Hanchard em projeto de influência intelectual norte-americana, denominado por eles de imperialismo cultural ou intrusão etnocêntrica. Ver os desdobramentos desse debate nesse número dos Estudos Afro-Asiáticos que conta com a contribuição de importantes especialistas em Brasil e relações raciais com o objetivo de debater as questões apresentadas no artigo de Bourdieu e Wacquant e uma resposta de Hachard (2002). 
No caso da posição da militância negra petista, a influência dos Estados Unidos está relacionada também à representação que se tem desse país no campo da esquerda. A oposição aos Estados Unidos é um elemento constitutivo do imaginário da esquerda latino-americana. Por isso, para alguns dos militantes negros, uma política identificada com esse país é avaliada por meio dos valores geralmente associados à sociedade norte-americana: individualismo, competitividade, consumismo, etc.

Para outros militantes, a direção que a política de combate ao racismo ganhou no Brasil exige uma revisão das bases teóricas que alimentaram a formação do movimento negro contemporâneo. É essa a perspectiva que está presente no depoimento de Nilo Rosa, ${ }^{21}$ ao referir-se ao Movimento Negro Unificado. Ele próprio, em um momento da entrevista, diz que hoje ele não é mais revolucionário, que a defesa que faz das políticas de cotas é reformista, mas aponta isso como algo positivo, a necessidade de ver outros caminhos:

Eu me lembro como se fosse hoje um dia que eu perguntei a Luis Alberto ${ }^{22}$ o que ele achava das cotas, das ações afirmativas. Eu perguntei, ele desconversou, disse que era contra, disse que era um negócio complicado, ele desconversou. O MNU nunca colocou, isso tem que ser bem claro, pra ninguém depois dizer que é o pai das cotas, nunca colocou claramente cotas para negro na universidade. Por um motivo muito simples, a base teórica do Movimento Negro Unificado é uma base marxista. É uma base marxista. Então se é uma base marxista acredita em classe, né? Eu não sei como a gente convive com isso, mas essa é a verdade. Ou assume essa realidade e passa a discutir outros paradigmas teóricos ou a gente vai ficar fingindo que está fazendo política.

Apesar de as ações afirmativas significarem uma inflexão na direção construída por aqueles setores da militância negra influenciados pela perspectiva de transformação da sociedade, a aceitação dessas políticas, também por esses segmentos, se faz a partir do entendimento que o sexo, a raça/etnia "são

21 Entrevista realizada no dia $1^{\circ}$ de agosto de 2008 em Goiânia no V COPENE (Congresso Nacional de Pesquisadores Negros). Nilo Rosa começou sua militância no PT de Salvador em 1986, e em 1992 entrou para o MNU (Movimento Negro Unificado), movimento do qual era coordenador na cidade de Salvador no momento da entrevista realizada no dia I de agosto 2008 em Goiânia no V COPENE (Congresso Nacional de Pesquisadores Negros).

22 Nilo Rosa faz referência ao deputado federal pelo PT e militante do MNU da Bahia, Luiz Alberto Silva dos Santos, deputado federal (2007-20II) licenciado para exercer o cargo de Secretário de Promoção da Igualdade do Estado da Bahia, de 6 de fevereiro de 2007 a II de agosto de 2008. 
construções sociais, usadas, precisamente, para monopolizar recursos coletivos" (GUIMARÁES, 1999, p.158) e que a quebra desse monopólio, por meio de políticas públicas específicas, é legítima. É essa ideia que encontramos na posição de Benedita da Silva - e que está também na visão de Milton Barbosa relatada acima:

Para finalizar, com relação à questão de cotas, reparações e ações afirmativas, temos de garantir o debate com a sociedade, e não podemos manipular seu pensamento majoritário. Acho que enriquecemos o debate e crescemos com ele, pois somos capazes de defender nosso ponto de vista na sociedade. E a sociedade discute cotas sim; discute reparações e ações afirmativas, que chamo de ação de inclusão e de equidade. Não é possível que o Partido dos Trabalhadores não faça verdadeiramente essa discussão, sob pena de termos um encaminhamento, uma diretriz política que não tenha absolutamente nada a ver com o Estado que queremos. Quero ver se com Lula governando este país não teremos ações afirmativas. Enquanto não construirmos esse tal socialismo, que tanto esperamos, e queremos, temos de construir algo que dê condição ao trabalhador negro, à trabalhadora negra, de pensar que podem, sim, e que têm sim, direitos. E para isso é preciso implementarmos políticas com viés de corte racial. Por isso as políticas públicas que defendo têm esse recorte (SILVA, 2005, p.55).

\subsection{A tomada de posição: convertendo-se às políticas de ação afirmativa}

A militância negra foi levada pela conjuntura a ter que definir um posicionamento diante das políticas afirmativas e de cotas. Como efeito da inserçáo da proposta de cotas no documento que o Comitê brasileiro levou a Durban e da cobertura que imprensa conferiu ao tema nos meses que precederam a Conferência, alguns projetos de leis começaram a ser votados e sancionados tendo como objeto cotas para negros nas universidades públicas. Em novembro de 2001, Antony Garotinho, entáo governador do Rio de Janeiro, sancionou a lei 3708/01 de autoria do deputado José Amorim do Partido Progressista (PP), aprovada por unanimidade pela Assembleia Legislativa do Rio de Janeiro em outubro de 2001. O projeto de lei de Amorim estabelecia cota mínima de 40\% para estudantes negros e pardos nos cursos de graduaçáo da UERJ (Universidade Estadual do Rio de Janeiro) e da UENF (Universidade Estadual Norte Fluminense). Em sua dissertaçáo de mestrado Michelle Peria (2004) descreve, com riqueza de detalhes, o processo de aprovaçáo dessa lei, proposta por um político sem histórico de ligação com as organizaçóes do 
movimento social negro e, surpreendentemente, acolhida unanimemente pela Assembleia Legislativa do Rio de Janeiro e, um mês depois, sancionada pelo governador Antony Garotinho. Junto com ela, Garotinho sancionou outra lei, a 3.524, que reservava 50\% das vagas da UERJ e da UENF para estudantes oriundos da escola pública. Ambas foram aplicadas no vestibular de $2003^{23}$.

Em 2002, foi a vez de a UNeB (Universidade Estadual da Bahia) estabelecer a cota mínima de $40 \%$ para a população afrodescendente, oriunda da escolas públicas, nos cursos de graduação e pós-graduação. A despeito das polêmicas que essas ações provocaram, o estabelecimento de uma cota para negros nas universidades públicas começou também a ser debatido pelas universidades federais.

Também em 2002 o senado recuperou o projeto de Lei no 650/1999, originalmente do senador José Sarney, que institui cota mínima de $20 \%$ para os afro-brasileiros nos serviços públicos e nos cursos de nível superior ${ }^{24}$, que tramitou como PL 6912/2002. Essa proposta estava em sintonia com outro projeto, $\mathrm{n}^{\circ} 3.198$, apresentado em junho de 2000 pelo então deputado Paulo Paim do PT do Rio Grande do Sul. O projeto de Paim previa a instituição do Estatuto da Igualdade Racial em defesa dos que sofrem preconceito ou discriminação em função de sua etnia, raça, e/ou cor, e também contava com a proposição de cotas para negros na educação, serviços públicos e mercado de trabalho. Em 2002, ambos os projetos foram apensados para tramitarem em conjunto.

Esses são alguns exemplos de ações que passaram a ser propostas e debatidas, e algumas implementadas pelo poder público nas esferas nacionais, estaduais e municipais e tiveram como consequência levar o tema das açóes

23 Em 2003, diante das reações às reservas de vagas, expressas nos números de liminares judiciais contra as Universidades, especialmente a UERJ, representantes do governo propuseram um debate com algumas organizações do movimento negro e representantes das universidades implicadas para o aperfeiçoamento da lei de cotas. Desse processo resultou a lei n. 4161/03 que se caracteriza pela diminuição percentual de cotas e uma substituição dos termos negros e pardos para afrodescendentes. Além de uma ênfase no critério econômico, inexistente no projeto anterior. Ver Conselho Superior de Ensino Pesquisa e Extensão da UERJ. Acesso à universidade por meio de ações afirmativas (2004). Disponivel em: <http://lpp-uerj.net/olped/ documentos/0824.pdf>. Acesso em: 14 jan. 2009.

24 Ver Rosana Heringer. Ação Afirmativa, estratégias pós-Durban. Observatório da Cidadania, 2002. Disponivel em: < http://www.socialwatch.org/es/informelmpreso/pdfs/panorbrasileirob2002_bra.pdf >. Acesso em: 18 jan. 2009. Nesse artigo Heringer (2002) apresenta um quadro com várias iniciativas e propostas de ações afirmativas, nas três esferas do poder público e nas diversas instâncias do poder federal, entre as quais se sobressai a política de cotas. 
afirmativas e das cotas para a disputa na sociedade. Essa realidade conferiu legitimidade à noção de cidadania diferencialista que estava no cerne das demandas por açôes afirmativas e forçou a adesão pública da militância negra a essas políticas.

Apesar da rapidez com que se publicizou o debate sobre açóes afirmativas, a demanda por essas políticas não resultou de um projeto político do movimento negro. Ela foi sendo pontuada em situaçóes particulares, por um ou outro militante, aparecendo em uma ou outra ação dos ministérios, em uma ou outra proposta política, sem que representasse um consenso no movimento negro, sem que ele estivesse organizado em torno de sua implementação.

Um exemplo disso é a dificuldade que encontramos nos discursos da militância em precisar a gênese desse salto do movimento negro brasileiro para as políticas públicas diferencialistas e para a política de cotas em especial: quem propôs, quando, respaldado em quê, ou mesmo quando, individualmente eles passam a defender essas políticas. Nessa situação, o debate público, as polêmicas, as primeiras iniciativas e o processo de conversáo a elas ocorreram simultaneamente. Considerando a trajetória de politização da questão racial na sociedade brasileira, que sempre esbarrou no mito da democracia racial, não havia expectativa por parte da militância negra de que a distância entre a proposição de cotas no documento de Durban em 2001 e a implementação dessas políticas fosse tão curta.

A rapidez com que essas políticas foram acontecendo apresentou novos desafios para a militância negra, o que Hédio Silva Júnior (ALBERTI e PEREIRA, 2007) sintetiza ao afirmar que a:

[...] luta contra o racismo no Brasil andou mais rápido do que a organização [...] A proposta de ação afirmativa, por exemplo, não resultou de nenhum planejamento adrede, calculado, planejado e tal. A gente ousou propor, e um conjunto de fatores contribuiu para que isso emplacasse. Mas não é razoável que luta ande mais rápido do que a organização. Você tem que ter uma organização capaz de gerir, digamos assim, esse novo momento, que é um momento absolutamente rico, em que nunca se discutiu tanto o tema do racismo. Mesmo a mais conservadora das instituições, ou a mais conservadora das três esferas de poder, que é o Judiciário, está tendo que se debruçar sobre isso (p. 453).

Resta esclarecer que a conversão da militância negra petista às ações afirmativas por meio da aceitaçáo da perspectiva de cidadania diferencialista não 
se contrapóe ao universalismo guiado que alimentava o entendimento dessa militância do que deveriam ser as políticas especiais para a população negra e que estava difundido pelas organizaçóes do movimento social negro. Não se trata de uma escolha entre o universal e o particular. A proposição de açóes afirmativas está associada às demandas por ampliaçáo e intensificaçáo de políticas universalistas, mesmo que as disputas em torno das relaçóes raciais na sociedade brasileira tendam a ofuscar essa dimensão. Talvez seja necessário, em algum momento, nos determos sobre os significados desse silêncio.

Se voltarmos ao documento que o movimento negro entregou ao presidente Fernando Henrique Cardoso em 1995, veremos que as propostas são bastante amplas e guiam-se também pelo princípio de universalidade. Entre as propostas para a educação o movimento reivindica, por exemplo, a:

recuperação, fortalecimento e ampliação da escola pública, gratuita e de boa qualidade; desenvolvimento de programa educacional de emergência para a eliminação do analfabetismo; concessão de bolsas remuneradas para adolescentes negros de baixa renda para o acesso e conclusão do primeiro e segundo graus ${ }^{25}$.

Assim como são diversas as propostas contra a discriminação e a intolerância que o Brasil levou a Durban ${ }^{26}$.

As políticas de ações afirmativas e a políticas de cotas são elementos constitutivos de uma proposta que tem várias dimensôes e visam a diferentes caminhos para eliminar os processos de subordinação aos quais estão submetidos a populaçáo negra.

A dimensão crítica das políticas específicas reside no fato de elas problematizarem a visão de igualdade presente na concepção liberal clássica que confunde igualdade com homogeneidade e de desvelarem os vínculos existentes entre universalidade e branquitude. Apesar da aparência de neutralidade que encobre o universal, nós sabemos que ele é produto de configurações históricas que favoreceram determinados grupos, os quais se constituíram enquanto dominantes, universais, neutros.

25 Documento apresentado ao Sr. Presidente da República do Brasil, em 20 de novembro de 1995, fruto da Marcha Zumbi dos Palmares, contra o racismo, pela cidadania e pela vida. Disponivel em: <http://www. leliagonzalez.org.br/material/Marcha_Zumbi_1995_divulgacaoUNEGRO-RS.pdf>. Acesso em: 27 maio 2009.

26 Cf. Plano Nacional de Combate ao Racismo e à Intolerância. Carta do Rio. Rio de Janeiro, 8 de julho de 2001. Disponivel em: <http://lpp-uerj.net/olped/documentos/ppcor/02/2.pdf>. Acesso em: 18 de maio 2008. 
As análises da realidade, por meio de dados estatísticos, mostram que, a despeito das políticas públicas universais na área da educaçáo, saúde, emprego, habitação, a população negra mantém um déficit em relação a esses direitos quando comparada com a população branca. Os dados estatísticos que passaram a ser produzidos e analisados visando a detectar o grau de desigualdade racial existente na sociedade têm tido cada vez mais um papel legitimador das políticas diferencialistas em razão de mostrarem que existem aspectos na interação social que funcionam como um obstáculo à vivência da universalidade.

O desnudamento dessa realidade favoreceu a legitimação dessas políticas entre os setores da militância negra de esquerda, assim como em outros espaços da sociedade, também em razão de ganharem visibilidade no contexto de refluxo dos projetos de transformação da sociedade, que já não conseguem ter ressonância junto à maioria da população, seja ela branca ou negra. Realidade que tornou a articulação entre raça e classe como estratégia para a politizaçáo da questão racial muito débil politicamente e, portanto, incapaz de produzir resultados concretos para a população negra.

No entanto, se ainda era possível encontrar resistências ou oscilaçóes entre alguns militantes em relação a essas políticas, quando eram chamados a definir um posicionamento público ou a militar em prol delas, não era só a trajetória passada que estava em questão. Havia por parte desse setor da militância a compreensão dos limites dessa abertura do Estado e da sociedade brasileira para a diferença em um momento de ameaças aos benefícios universais que poderia favorecer a maioria da população negra, majoritariamente pobre.

A bandeira da diferença tem sido utilizada pelo movimento negro como uma estratégia política que tem como meta a ampliação da cidadania e a constituição de uma cultura de direitos na sociedade brasileira. No entanto, a conjuntura na qual isso ganha relevo mostra que os significados da cidadania e da própria política da diferença só podem ser definidos no campo da luta política - uma vez que o projeto de ampliação dos direitos tem se debatido na sociedade contemporânea com o projeto neoliberal. Este caracterizado pela política de regressão de direitos, sustentado em uma visão de cidadania contrária àquela construída pelos movimentos sociais, que na prática implica regressão dos direitos já conquistados. A incorporaçáo da diferença à cidadania e a sua institucionalização ocorreram em um cenário de restrição da ampliação da cidadania, o que Gurza Lavalle (2003) denomina de ironia histórica: "o reconhecimento da diferença, porém, sem equidade" (p. 76). 
Esse contexto justifica as reservas de parte da militância negra sobre a possibilidade de surgimento de uma elite, classe média ou burguesia negra sem solidariedade racial com a população negra pobre e sem compromissos políticos com a ampliação da igualdade. Todavia, o alcance da política está para além do público que ela pode atingir. Ela beneficia também esses setores da população quando incidem sobre o autoritarismo social característico das relações sociais na sociedade brasileira. Os ganhos dessas políticas para toda a população negra, e não somente para os grupos que delas se beneficiam, advêm das alteraçóes que provocam no modelo de representação cultural dominante. Ao produzirem uma sociedade mais plural nos vários espaços de interação social e não somente naqueles onde está concentrada a pobreza, ao colocarem essa mesma sociedade diante de suas diversas fontes de desigualdades, essas políticas contribuem para o enriquecimento dos valores democráticos e para o reconhecimento do outro como sujeito de direitos, não só em uma perspectiva do alcance das alteraçóes legais, definidas pelo Estado, mas também na sociedade.

Está em andamento na sociedade brasileira o questionamento da concepção autoritária pautada na ideia de lugar social do negro que, redefinido pelo mito da democracia racial, restringi-se a espaços culturais bem específicos: o futebol, a música, a capoeira, a malandragem; e na dimensão econômica aos espaços mais subalternizados e de pior remuneração. Se aceitarmos que a cultura é também fonte de dominação, essas políticas, ao problematizarem os modelos dominantes de representação cultural e desnudarem as relaçóes de poder que eles escondem, tendem a beneficiar toda a populaçáo, pois inserem novos significados culturais nas práticas sociais cotidianas.

O compromisso com políticas específicas para a população negra e de sua valorização cultural, em uma perspectiva de radicalizaçáo da democracia, deve estar combinado com políticas de combate à pobreza e de promoção do bem-estar social. Caso contrário, corre-se mesmo o risco de criar no interior da população negra uma fragmentação entre uma elite com acesso ao conteúdo da vida civilizada (MARSHALL, 1987) e a grande maioria da população negra, submetida a processos de exclusão cada vez mais severos.

\section{Considerações finais}

A reconstrução da trajetória recente de politização da questão racial no Brasil - considerando a conjuntura do processo de redemocratizaçáo da sociedade 
brasileira à inclusão na esfera pública do debate sobre ações afirmativas para a populaçáo negra - nos levou a identificar os encontros e desencontros entre o movimento social negro e o campo da esquerda e os dilemas da militância negra identificada com a esquerda diante das proposiçóes de políticas afirmativas.

Em nossa análise foi possível mapear uma dinâmica que se manteve constante na relaçáo entre a militância negra e as organizaçóes de esquerda: uma tensão, provocada pelo fato de essas organizaçôes compreenderem a luta política a partir da centralidade da luta de classes e de um projeto de transformação estrutural referenciado às classes trabalhadoras. A militância negra que foi socializada politicamente nesse campo, seja por sua atuação no movimento sindical, nas organizaçóes clandestinas de esquerda, ou no ambiente universitário, viu nesse projeto a possibilidade de politização da questão racial no Brasil.

Porém, ao partilharem o cotidiano dessas organizaçóes, logo percebiam que o projeto de transformação social, a partir de um sujeito específico - a classe trabalhadora - dificultava ou mesmo impedia que os temas desigualdades, discriminaçôes e preconceitos raciais fossem transformados em questão política.

A tendência era que essas organizaçóes subsumissem esse debate na luta de classes. Não obstante essas dificuldades, a esquerda era uma referência política fundamental para setores significativos da militância negra. A experiência da militância negra no PT mostra que, embora ela tencionasse com o partido, era como parte do projeto de transformaçáo social que ela compreendia a politização da questão racial no Brasil. É essa filiação que transformou a adesão às políticas de açóes afirmativas de uma forma geral e a políticas de cotas em particular em um dilema para essa militância.

A partir da década de 1990, o campo do movimento social negro tornou-se mais complexo com o surgimento de novas organizaçóes e novas propostas de encaminhamento para a problemática das desigualdades raciais na sociedade brasileira, que levaria ao tema das açóes afirmativas.

Essa questáo aparece de forma embrionária com a Marcha a Brasília em 1995, mas só se populariza a partir da Conferência Mundial de Combate ao Racismo em 2001, que introduziu a política de cotas na agenda política brasileira, retirando o debate da questáo racial dos espaços restritos e específicos e levando-o para a disputa na sociedade. 
É essa a conjuntura que vai exigir que a militância negra adote uma posição pública diante dessas políticas, pois ela deveria se preparar para travar o debate e a disputa na sociedade. $\mathrm{O}$ fato de no Brasil as açóes afirmativas terem se popularizado por meio da política de cotas, tornou a tomada de decisão mais urgente e mais difícil para a militância que tinha construído a sua trajetória referenciada ao pensamento de esquerda. $\mathrm{O}$ debate avançaria rapidamente, em razão das propostas incidirem sobre o cotidiano e os processos de sociabilidade com a presença de alunos negros cotistas nas universidades públicas. Os encaminhamentos em direção a essas políticas tiveram como efeito positivo provocar e despertar a sociedade para um tema habituado à invisibilidade. De repente todos passaram a se interessar pelas relaçôes raciais no Brasil: o Estado, as universidades, a mídia, a esfera jurídica, os intelectuais, a direita e a esquerda etc.

E é nessa conjuntura que captamos o desafio que a definição de uma posição favorável às políticas afirmativas, via política de cotas, significou para um setor da militância negra brasileira. Embora esse trabalho tenha tomado o PT como referência, temos evidências que nos autorizam a crer que o dilema vivido pela militância negra petista foi compartilhado por militantes negros em outros espaços. Se, por um lado, a filiação a essas políticas colocava em questão a forma como historicamente - desde o ressurgimento do movimento negro na década de 1970 - fora concebida a luta política no campo do combate ao racismo; por outro, deixava pouco espaço para a oposiçáo ou o silêncio. Seja pela evidência do papel desempenhado pela raça na manutenção de hierarquias sociais, ou ainda em razão do refluxo das agendas políticas construídas pela esquerda - que enfraquecia a ressonância de um eixo organizativo centrado em raça e classe -, também esses setores se convenceram ou foram convencidos da legitimidade de políticas específicas e da política de cotas para a população negra.

O fato de o PT ter ganhado as eleiçóes presidenciais de 2002 e o presidente eleito Luiz Inácio Lula da Silva ter se mostrado simpático a essas políticas - e além disso, sob a pressão do movimento social negro, ter criado a SEPPIR (Secretaria Especial de Políticas de Promoção da Igualdade Racial) e sancionado a lei 10.639 em 2003 - acelerou o processo de filiação da militância negra petista a essa resposta às desigualdades raciais na sociedade brasileira e uma nova compreensão dos caminhos a serem trilhados em prol da igualdade racial na sociedade brasileira. 


\section{Referências}

AlberTi, V.; PEREIRA, A. A. (Org.). Histórias do Movimento Negro: depoimentos ao CPDOC. Rio de Janeiro: Pallas, CPDOC-FGV, 2007.

ANDREWS, George Reid. Negros e brancos em Sáo Paulo 1888-1988. Bauru: Edusc, 1998.

BOURDIEU, P.; WACQUANT, L. Sobre as artimanhas da razão imperialista. Estudos AfroAsiáticos, ano 24, n.1, 2002.

CARNEIRO, S. Entrevista. Revista Caros Amigos, São Paulo, n. 35, fev. 2000.

CONSELHO SUPERIOR DE ENSINO PESQUISA E EXTENSÃO da UERJ. Acesso à universidade por meio de açóes afirmativas (2004). Disponível em: <http://lpp-uerj.net/olped/ documentos/0824.pdf.> Acesso em: 14 jan. 2009.

DIRETÓRIO NACIONAL do PT. Partido dos Trabalhadores: resoluçóes de encontros e congressos. São Paulo: Fundação Perseu Abramo, 1998.

FERNANDES, F. Luta de raças e de classes. Teoria e Debate, São Paulo, n. 2, mar. 1988.

FRASER, N. Qu'est-ce que la justice sociale? Reconnaissance et redistribution. Paris: La Découverte, 2005.

GONZALEZ, L.; HASENBALG, C. Lugar do Negro. Rio de Janeiro: Marco Zero: 1982.

GUIMARÃES, A. S. A. Argumentando pela ação afirmativa. In: . Racismo e Anti-Racismo no Brasil. São Paulo: Editora 34/FUSP. 1999.

GURZA LAVALlE, A. Cidadania, Igualdade e Diferença. Lua Nova, São Paulo, n.59, p.75-93, 2003.

HANCHARD, M. G. Orfeu e o poder. Trad. Vera Ribeiro. Rio de Janeiro: Ed. Uerj, 2001.

HERINGER, R. Ação Afirmativa, estratégias pós-Durban. Observatório da Cidadania, n. 55, 2002. Disponível em: <http://www.socialwatch.org/sites/default/files/pdf/en/panorbrasileirob2002_bra. pdf > Acesso em: 18 jan. 2009.

MARSHALL, T. H. Cidadania e classe social. In:__. Cidadania, classe social e status. Rio de Janeiro: Zahar Editores, 1987.

MENDOÇA, L. Movimento Negro: da marca da inferioridade racial à construção da identidade étnica. São Paulo, 1996. Dissertação (mestrado) Faculdade de Filosofia, Letras e Ciências Humanas da Universidade de São Paulo, 1996.

MENDONÇA, M.; BENJAMIM. Benedita. Rio de Janeiro: Mauad, 1997. 
MOURA, C. Organizações Negras. In: SINGER, Paul.; BRANT, Vinicius Caldeira (Org.). São Paulo: o povo em movimento. São Paulo: Vozes/ Cebrap, 1980.

NASCIMENTO, A.; NASCIMENTO, E. L. Reflexôes sobre o movimento negro no Brasil, 1938-1997. In: GUIMARÃES, A, S. A.; HUNTLEY, L. (Org.). Tirando a máscara: ensaios sobre o racismo no Brasil. São Paulo: Paz e Terra, 2000.

ORTIZ, R. Cultura brasileira e identidade nacional. São Paulo: Brasiliense, 1985.

PAOLI, M. C. Movimentos sociais no Brasil: em busca de um estatuto político In: Helmann, M. (Org.) Movimentos sociais e democracia no Brasil. São Paulo: Marco Zero, 1995.

PERIA, M. Açáo afirmativa: um estudo sobre reserva para negros nas universidades públicas brasileiras: o caso do Estado do Rio de Janeiro. Rio de Janeiro. Dissertação (Mestrado em Antropologia). Universidade Federal do Rio de Janeiro, 2004.

PINTO, R. P. O movimento negro em Sáo Paulo: luta e identidade. São Paulo, 1993. Tese (Doutorado em Sociologia). Universidade Estadual de São Paulo, 1988.

RAÇA \& CLASSE, Brasília, ano 2, n. 6, mai/ jun. 1989.

RIBEIRO, M. Entrevista. In: Revista Caros Amigos, ano 13, n. 145, abr. 2009.

RIDENTI, M. S. “Ação Popular: cristianismo e marxismo”. In: REIS FILHO, D. A.; Ridenti, M. (Org.). História do marxismo no Brasil, 5: Partidos e organizações dos anos 20 aos 60. Campinas: Editora da UNICAMP, 2002.

SANSONE, L. Racismo sem etnicidade, políticas públicas e discriminaçáo racial em perspectiva comparada. Dados, v. 41, n.4, Rio de Janeiro, 1998.

SANTOS, G. G. Partidos políticos e etnia negra. São Paulo, 1992. Dissertação (Mestrado em Sociologia) Pontifícia Universidade Católica de São Paulo, 1992.

SCHERER-WARREN, I; LÜCHMANN, L. H. H. Situando o debate sobre movimentos sociais e sociedade civil no Brasil Introdução. Política \& Sociedade, n.05, p. 13-36, out. 2004.

SCHWARCZ, L., M. De festa também se vive: reflexôes sobre o centenário da Abolição em São Paulo. Rio de Janeiro: CIEC-UFRJ, 1989.

SILVA JÚNIOR, H. Depoimento. In: ALBERTI, V.; PEREIRA, A. A. (Org.). Histórias do Movimento Negro: depoimentos ao CPDOC. Rio de Janeiro: Pallas, CPDOC-FGV, 2007. . Entrevista. Isto é. São Paulo, n.1876, set. 2005. . Uma conversa que não pode ficar só entre negros. Boletim Nacional, n. 27, maio, 1987. 
SILVA, B. Comentários In: IANNI, O, et. al. O negro e o socialismo. São Paulo: Editora Fundaçáo Perseu Abramo, 2005.

SILVA, B. Entrevista. Boletim Nacional, n.54, nov. 1991.

SILVA, F. J. R. Os negros no PT: organizar e transformar. Boletim Nacional, n. 35, maio, 1987.

SILVA, O. A. As organizações e o PT: uma concepção do caráter socialista da revoluçáo brasileira. In: __. História das tendências no Brasil (Origens, cisões e propostas). São Paulo: Proposta Editorial, 1987.

SOARES, C. G. Raça, classe e cidadania: a trajetória do debate racial no Partido dos Trabalhadores (1980-2003). Campinas, 2009. Tese (Doutorado em Sociologia) Universidade Estadual de Campinas, 2009.

\section{Entrevistas por ordem alfabética}

Flávio Jorge Rodrigues da Silva, 06/11/2007, na Fundação Perseu Abramo, São Paulo.

Gevanilda Gomes dos Santos, 07/11/207, na Soweto Organização Negra, São Paulo.

Hédio Silva Júnior, 27/01/2009, por e-mail.

Matilde Ribeiro, 05/11/2007, no Hotel Pestana, São Paulo.

Milton Barbosa, 18/04/2008, em sua residência na zona oeste de São Paulo.

Nilo Rosa, 01/08/2008, em Goiânia no V COPENE (Congresso Nacional de Pesquisadores Negros).

Rafael Pinto, 20/08/2008, na AFUBESP (Associação dos Funcionários do Grupo Santander Banespa, Banesprev e Cabesp), na cidade de São Paulo.

\section{Documentos}

Comissão de Negros do PT - Partido dos Trabalhadores. O negro e o Partido dos Trabalhadores. Documento cedido por Milton Barbosa em entrevista no dia 18/04/2008.

Subsecretaria Nacional de Negros do PT. Políticas sociais para a populaçáo negra no Plano Alternativo de Governo, 1989. (Documento cedido por Flávio Jorge Rodrigues da Silva)

Documento apresentado ao Presidente da República do Brasil, em 20 de novembro de 1995, fruto da Marcha Zumbi dos Palmares, contra o racismo, pela cidadania e pela vida. Disponível em: 
<http://www.leliagonzalez.org.br/material/Marcha_Zumbi_1995_divulgacaoUNEGRO-RS.pdf>. Acesso em: 27 maio 2008.

Plano Nacional de Combate ao Racismo e à Intolerância. Carta do Rio. Rio de Janeiro, 8 de julho de 2001. Disponível em: <http://lpp-uerj.net/olped/documentos/ppcor/0212.pdf >. Acesso em: 18 de maio 2008.

\section{Race, class, and affirmative action in the political history of black militants from the left}

\section{Abstract}

Ten years passed since the Conferência Mundial de Combate ao Racismo (International Conference Against Racism) (200I), it is possible to say that Brazilian society is adapted to the experiences of affirmative actions for black population. However, when this debate was started in 200 I, crossed by all kinds of polemic issues, it was also new for militants in the black social movement. This paper will deal with dilemmas and challenges that were present in the conversion of opposition black militancy to affirmative actions. Our analysis will have as reference the experience of black militancy that acted on Partido dos Trabalhadores (Workers Party), which supported the articulation between race and class as a strategy of politicization of racial issues. The adhesion of this sector of militancy to affirmative actions policies for black population meant a confrontation with ideological and political conceptions constructed in the opposition field.

Keywords: Affirmative actions. Social classes. Citizenship. Black social movement. Partido dos Trabalhadores (Workers Party). 